\title{
MENINGKATKAN KEMAMPUAN PEMECAHAN MASALAH MATEMATIK SISWA MA DENGAN MENGGUNAKAN PENDEKATAN OPEN ENDED
}

\author{
Agung Nugraha ${ }^{1}$,Irpan Mulyana ${ }^{2}$ Masta Hutajulu $^{3}$, Asep Ikin Sugandi ${ }^{4}$ \\ ${ }^{123}$ IKIP Siliwangi, JL. Terusan Jendral Sudirman, Cimahi, Jawa Barat, Indonesia \\ 19Agungnugraha865@gmail.com,2irpanmulyana26@yahoo.com,3 hutajulu@stkipsiliwangi.ac.id \\ 4sugandi@stkipsiliwangi@.ac.id
}

\begin{abstract}
This research is based on the problem of the low mathematical problem solving ability of students who have a relationship with someone's success in solving a problem that they face. In this case, to overcome this, a class of research was conducted using an open ended approach and ordinary learning. In addition, this research is a quasi-experimental. The population in this study were students of class X MA in Bandung in 2018/2019 academic year. The research sample is all Class X students in one MA in Bandung. Quantitative analysis was performed using the two-difference test and descriptive qualitative analysis was also carried out. The results showed that the ability to solve mathematical problems using the open ended approach was better than those using the usual approach.
\end{abstract}

Keywords: Ability to Solve Mathematical Problems, Open Ends

\begin{abstract}
Abstrak
Pada penelitian ini didasarkan pada permasalahan rendahnya kemampuan pemecahan masalah matematik siswa yang mempunyai hubungan dengan keberhasilan seseorang dalam menyelesaikan suatu permasalah yang dihadapinya. Dalam hal ini untuk mengatasi hal tersebut, dilakukan penelitian dikelas menggunakan pendekatan open ended dan pembelajaran biasa. Selain itu, penelitian ini merupakan kuasi eksperimen. Populasi pada penelitian ini adalah siswa kelas X MA di Kota Bandung Tahun Pelajaran 2018/2019. Sampel penelitiannya adalah seluruh siswa Kelas X di salah satu MA di Kota Bandung. Analisis kuantitatif dilakukan dengan menggunakan uji perbedaan dua rata-rata dan dilakukan juga analisis kualitatif secara deskriptif. Hasil penelitian menunjukkan bahwa kemampuan pemecahan masalah matematik yang menggunakan pendekatan open ended lebih baik daripada yang menggunakan pendekatan biasa.
\end{abstract}

Kata Kunci: Kemampuan Pemecahan Masalah Matematik, Open Ended

How to cite: Nugraha, A., Mulyana, I., Hutajulu, M., Sugandi, A. I. (2019). Meningkatkan Kemampuan Pemecahan Masalah Matematik Siswa MA dengan Menggunakan Pendekatan Open Ended. JPMI - Jurnal Pembelajaran Matematika Inovatif, 2 (5), 361-370.

\section{PENDAHULUAN}

Sebagai salah satu mata pelajaran dinilai cukup memegang peranan penting untuk menjadikan siswa menjadi berkualitas, matematika merupakan suatu sarana berpikir untuk mengkaji secara logis serta sistematis (Nurfauziah \& Zhanthy, 2018). Selain itu matematika menjadi dasar ilmu pengetahuan yang wajib dimiliki oleh masing-masing siswa walupun terkadang pelajaran matematika sering dianggap pelajaran yang rumit, membosankan dan menakutkan. Di era industri 4.0, matematika juga adalah dasar dalam perkembangan tekonologi 
yang saat ini mayoritas manusia sangat ketergantungan pada suatu teknologi di zaman ini. Oleh karena itu pendidikan mempunyai pernanan penting untuk mengembangkan serta membangun bangsa dan negara khususnya dalam IPTEK, sesuai dengan fungsi pendidikan tinggi dalam UU No. 12 Tahun 2012 (Hutajulu \& Minarti, 2017) menyebutkan sebagai pusat pengembangan Ilmu Pengetahuan dan Teknologi serta sarana untuk menghasilkan intelektual, ilmuwan, dan professional yang bersifat kreatif serta berbudaya untuk mencapai satu tujuan pokok bangsa yaitu meningkatkan daya saing dalam menghadapi era globlalisasi pada segala bidang tertentu

Pentingnya pembelajaran matematika menjadi alasan dipelajarinya matematika sejak pendidikan dasar hingga tingkat tinggi, sebab dengan pembelajaran matematika siswa belajar dan berlatih penataan dalam berpikir terutama dalam berpikir secara logis, kritis, menalar, serta mampu menganalisis serta mengevalusi dalam menyelesaikan persoalan permasalahan khususnya pada kehidupan sehari-hari. Pembelajaran matematika bukan hanya sebatas dalam menyelesaikan soal-soal atau menghafalkan rumus matematika, akan tetapi siswa juga harus mengetahui konsep dasar pada rumus. Keterkaitan antara konsep dasar dalam matematika terjalin sangat erat dan rapi, sehingga pemahaman suatu konsep akan sangat mendukung pemahaman terhadap konsep lainnya. Pemahaman konsep lainnya perlu dikembangkan kepada siswa sejak dini. Konsep dalam matematika merupakan konsep atau ide yang memberikan peluang kepada siswa untuk mengelompokan suatu tanda atau obyek kedalam contoh, sehingga siswa akan mengerti tentang definisi, pengertian, cara menjelaskan suatu permasalahan maupun cara pengoprasian suatu matematika. Oleh karena itu, dalam meningkatkan suatu kemampuan menjadi lebih penting dalam suatu pembelajaran matematika, kemampuan pemecahan masalah atau KPM merupakan satu dari sekian kemampuan yang harus dimiliki oleh masing-masing siswa.

Menurut Polya (Sugandi, 2010) KPM merupakan suatu usaha untuk mencari jalan keluar dari suatu kesulitan dalam mencapai tujuan yang tidak dengan segera diperoleh. KPM mampu menjadikan siswa menemukan pemikiran baru untuk memaksimalkan kemampuan siswa terutama dalam berfikir secara kritis, pada kemampuan tersebut akan memberikan arahan dalam melaksanakan suatu pekerjaan dalam berpikir. Selain itu, KPM akan membantu dalam mengaitkan suatu pokok pemasalahan dengan lebih jelas. Cooney (Soemarmo \& Hendriana, 2014) mengungkapkan bahwa dengan memiliki KPM akan membantu siswa berpikir secara analitik dalam mengambil keputusan di kehidupan sehari-hari serta akan membantu meningkatkan kemampuan berpikir kritis dalam menghadapi kejadian yang baru. Agar tercapainya suatu pembelajaran yang menjadikan siswa berpikir secara kritis dibutuhkan kerjasama dari semua siswa, kemampuan anak dalam berpikir kritis yaitu dengan mengembangkan kemampuan intelektual yang dimiliki siswa.

Pentingnya KPM juga sejalan dengan tujuan yang diungkapkan Depdiknas (Hutajulu, 2017) pada poin nomor tiga yaitu " memecahkan masalah matematik yang meliputi kemampuan memahami masalah, merancang model matematika, menyelesaikan model dan menafsirkan solusi yang diperoleh dari permasalahan tersebut ". Hasil dari pembelajaran matematika yang diharapkan untuk berhasil dimiliki siswa adalah kemampuan dalam memahami suatu konsep pada matematika. Siswa yang mengerti suatu konsep dengan baik dan benar akan mengetahui dengan lebih mendalami suatu konsep pemikiran pada materi matematika yang belum diketahui siswa. Pembelajaran yang dipelajari dengan pemahaman sendiri akan memberikan dasar dalam membentuk pengetahuan baru, sehingga dengan terbentuknya pemahaman dari suatu konsep, siswa mampu memberikan pendapat dalam menjelaskan pengetahuannya pada suatu konsep. 
Pentingnya pembelajaran dengan KPM belum sesuai dengan apa yang diharapkan dengan fakta di lapangan, KPM dapat disebut sangat rendah. Berdasarkan pada penelitian yang dilakukan oleh Akbar, Hamid, Bernard \& Sugandi (2018) diperoleh bahwa KPM matematik siswa SMA masih sangat rendah, hal ini terlihat dari mayoritas siswa yang pencapaian pembelajarannya pada beberapa indikator masih terlihat sangat rendah. Dari semua siswa yang telah mengikuti uji tes KPM matematik hanya 48,75\% yang mampu pada indikator memahami masalah, 40\% merencanakan penyelesaian, $7,5 \%$ pada indikator menyelesaikan masalah serta $0 \%$ pada indikator pengecekan kembali. Selain itu, hasil tes KPM matematik yang dilakukan oleh TIMSS 2007 menunjukan bahwa Indonesia berada pada posisi ke 36 dari 48 negara, ini menandakan bahwa KPM matematik di Indonesia masih tergolong sangat rendah (Yulianingsih, 2013) .

Kebiasan seorang pendidik atau guru yang melakukan pembelajaran dengan model ceramah atau pembelajaran satu arah menjadi salah satu penyebab rendahnya KPM matematik, sehingga perlulah suatu pendekatan yang sesuai untuk meningkatkan KPM. Pendekatan yang diduga mampu meningkatkan KPM salah satunya adalah pendekatan open ended. Menurut Sawada (Faridah, Atun dan Aeni, 2016) pendekatan open ended adalah pendekatan dalam pembelajaran ketika guru atau pendidik memberikan suatu situasi masalah kepada siswa yang jawabannya dapat diperoleh dengan banyak cara. Adapun langkah-langkah yang perlu dilakukan pada pembelajaran dengan pendekatan open ended menurut Shimada (Delyana, 2015) adalah 1) Pembelajaran haruslah dimulai dengan memberikan permasalahan terbuka kepada siswa, 2) Beragam kegiatan yang dilakukan untuk menyelesaikan permasalahan yang dihadapi, 3) memberikan alokasi waktu yang cukup untuk siswa mengeksplorasi masalah, 4) siswa membuat rangkuman dari hasil penemuan yang dilakukan, 5) evaluasi kebenaran jawaban dengan cara diskusi untuk menghasilkan kesimpulan yang baik dan benar dengan bimbingan guru. Langkah kegiatan yang dilakukan diharapkan ketika proses pembelajaran yang berlangsung dapat sesuai dengan keinginan serta pendekatan open ended yang diharapkan.

Nohda (Setiawan \& Harta, 2014) mengungkap pendekatan open ended sangat penting untuk setiap siswa dalam memiliki kebebasan agar dapat meningkatkan suatu KPM. Penggunaan pendekatan open ended juga siswa diharapkan mampu menemukan atau merencanakan strategi yang akan digunakan dalam menjawab suatu permasalahan yang diberikan. Dengan ini proses pembelajaran dikelas menggunakan pendekatan open ended dapat merangsang siswa untuk menyelesaikan atau memecahkan suatu masalah yang dihadapkan kepada siswa dengan berbagai macam strategi atau penyelesaian yang benar, bahkan siswa akan mampu mengembangkan suatu pola pikir dan pemahaman akan lebih baik. Selain itu, pendekatan open ended membuat siswa lebih aktif ketika pembelajaran berlangsung, serta lebih mengekplorasi dalam mencari solusi yang diharapkan, hal ini mampu meningkatkan kreatifitas serta kritis siswa dalam berpikir.

Siswa merasa kesulitan ketika mengerjakan soal yang berbeda dengan contoh soal yang sebelumnya guru berikan, KPM matematik di kelas menjadi sangat tidak optimal, kurangnya melakukan usaha secara maksimal dalam menuntun siswa untuk menyelesaikan permasalahannya, menyebabkan soal-soal yang telah diberikan pendidik di sekolah biasanya cenderung bersifat memusat atau konvergen, jawaban serta strategi siswa dalam menyelesaikannya hanya dengan satu cara saja. Menyikapi permasalahan tersebut maka peneliti perlu melakukan pembelajaran pendahuluan untuk mengetahui suatu KPM matematik pada kelas X di salah satu Madrasah Aliyah Swasta di kota bandung. 


\section{METODE}

Metode penelitian ini adalah kuasi eksperimen, yang dilakukan guru dimana setiap saat sesuai dengan keadaan pembelajaran dikelas. Peneliti menggunakan dua kelompok, dengan menggunakan penelitian quasi experiment atau eksperimen semu. Penelitian ini dilakukan di MA Al-Istiqomah Kota Bandung pada tahun ajaran 2019/2010 pada kelas X yang berjumlah 5 kelas. Alasan pemilihan subjek sampel adalah karakteristik sampel mewakili karakter populasi. Adapun penelitian ini dilaksanakan pada bulan April sampai bulan Mei 2019. Adapun sampelnya yang dipilih dua kelas secara acak kelas. Berdasarkan teknik tersebut diperoleh sampel sebanyak dua kelas yaitu kelas X MIA-1 yang dijadikan untuk kelas eksperimen sebanyak 21 siswa, kelas X MIA-2 yang dijadikan untuk kelas kontrol 21 siswa. Desain penelitian ini yaitu dua kelompok penelitian, kelas eksperimen yang pembelajaran dengan menggunakan pendekatan open ended dan kelas kontrol dengan menggunakan pembelajaran langsung (Ruseffendi, 2010) berikut:

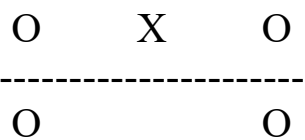

Keterangan :

$\mathrm{O} \quad:$ Postes $=$ Pretest $($ tes KPM $)$

$\mathrm{X} \quad$ : Pembelajaran pendekatan open ended

------ : subjek diambil secara tidak acak

Instrumen yang diberikan pada dalam penelitian ini adalah berbentuk tes. Instrumen yang digunakan untuk pengambilan data pada penelitian ini adalah KPM matematik yang berbentuk soal uraian sebanyak 5 soal. Dari masing-masing soal terdiri dari empat indikator KPM matematik. Indikator yang digunakan adalah menurut Polya (Hendriana \& Sumarmo, 2014) yaitu memahami masalah, merencanakan strategi, menyelesaikan masalah dan memeriksa kembali Data KPM matematik diperoleh berdasarkan nilai pretes dan postes. Penilaian hasil tes uraian KPM matematik yang digunakan mengacu dan diadaptasi dari Hendriana dan Sumarmo (2014). Kriteria pemberian skor untuk masing-masing indikator KPM matematik berikut pada Tabel 1.1 :

Tabel 1. Kriteria Pedoman Penskoran KPM Matematik

\begin{tabular}{|c|c|c|}
\hline Aspek yang Dinilai & Reaksi Terhadap Soal/Masalah & Skor \\
\hline \multirow{3}{*}{ Memahami Masalah } & Tidak ada jawaban & 0 \\
\hline & $\begin{array}{l}\text { Mengidentifikasi data diketahui, ditanyakan dan } \\
\text { kecukupan data/ unsur serta melengkapinya bila } \\
\text { diperlukan dan menyatakannya dalam simbol } \\
\text { matematika yang relevan }\end{array}$ & $0-2$ \\
\hline & $\begin{array}{l}\text { Menyusun model matematika masalah dalam } \\
\text { bentuk gambar dan atau ekspresi matematika }\end{array}$ & $0-2$ \\
\hline $\begin{array}{c}\text { Merencanakan } \\
\text { Penyelesaian }\end{array}$ & $\begin{array}{l}\text { Mengidentifikasi beberapa strategi yang dapat } \\
\text { digunakan untuk menyelesaikan model } \\
\text { matematika yang bersangkutan. }\end{array}$ & $0-2$ \\
\hline Menyelesaikan Masalah & $\begin{array}{l}\text { Menetapkan/memilih strategi yang paling } \\
\text { relevan dan menyelesaikan model matematika } \\
\text { berdasarkan gambar dan atau ekspresi } \\
\text { matematika yang telah disusun }\end{array}$ & $0-2$ \\
\hline \multirow{2}{*}{ Memeriksa Kembali } & Memilih atau menentukan solusi yang relevan & $0-2$ \\
\hline & Memeriksa kebenaran solusi kemasalah asal & $0-2$ \\
\hline Skor satu bu & tes pemecahan masalah matematik & 0-12 \\
\hline
\end{tabular}


Sebelum diberikan tes, peneliti membuat kisi-kisi soal dengan membuat kunci jawaban dan penskoran tiap butir soal. Kemudian peneliti mengujicobakan soal tes KPM bertujuan untuk mengetahui validitas, reliabilitas, tingkat kesukaran dan daya pembeda pada soal-soal tes KPM yang digunakan dalam penelitian.

Sedangkan, agar dapat mengetahui besarnya peningkatan KPM matematik siswa sebelum dan sesudah diberi tindakan dikelas, dilakukan perhitungan gain ternormalisasi menurut Menurut Hake (Aripin, 2015), sebagai berikut:

$$
\text { Gain ternormalisasi }(\mathrm{g})=\frac{\text { Skor tes akhir }- \text { skor tes awal }}{\text { skor maksimum ideal }- \text { skor tes awal }}
$$

Kategori dari gain ternormalisasi dikelompokkan kedalam tiga kategori yaitu:

Tabel 2. Klasifikasi Skor N-Gain

\begin{tabular}{cc}
\hline Besarnya Gain $(\mathbf{g})$ & Interpretasi \\
\hline $\mathrm{g}>0,70$ & Tinggi \\
$0,30 \leq \mathrm{g} \leq 0,70$ & Sedang \\
$\mathrm{g}<0,30$ & Rendah \\
\hline
\end{tabular}

\section{HASIL DAN PEMBAHASAN}

\section{Hasil}

Sebelum melakukan pembelajaran dikelas, diberikan 5 soal pretes yaitu dengan tujuan untuk mengetahui kemampuan awal sebelum diberikan perlakuan. Selanjutnya dilakukan postes untuk mengetahui kemampuan siswa setelah diberikan tindakan. Dari hasil pretes dan postes diperoleh skor $N$-gain untuk mengetahui peningkatan setelah diberikan tindakan.

Berdasarkan pada hasil penelitian diperoleh data deskriptif sebelum dan sesudah pembelajaran, maka didapatkan nilai rata-rata skor dan simpangan baku berikut pada Tabel 1.3:

Tabel 3. Deskripsi Data Hasil Penelitian

\begin{tabular}{cccccccc}
\hline \multirow{2}{*}{ Variable } & \multicolumn{3}{c}{$\begin{array}{c}\text { Pendekatan } \\
\text { Open Ended } \\
\text { (Eksperimen) }\end{array}$} & \multicolumn{3}{c}{$\begin{array}{c}\text { Pendekatan } \\
\text { Biasa } \\
\text { (Kontrol) }\end{array}$} \\
\cline { 3 - 8 } & & Pretes & Postes & N-Gain & Pretes & Postes & N-Gain \\
\hline \multirow{2}{*}{$N$} & & \multicolumn{6}{c}{21} \\
KPM & $X_{\text {Min }}$ & 0 & 6 & 0,07 & 0 & 8 & 0,04 \\
Matematik & $X_{\max }$ & 13 & 46 & 0,75 & 12 & 26 & 0,40 \\
& $\bar{X}$ & 3,76 & 29,29 & 0,46 & 3,24 & 15,86 & 0,22 \\
& $S$ & 3,65 & 12,70 & 0,21 & 3,87 & 5,55 & 0,08 \\
\hline SMI $=\mathbf{6 0}$ & & & & & & &
\end{tabular}

Berdasarkan Tabel 1.3 di atas, pada hasil pretes, postes, ngain yang bertujuan untuk mengetahui pencapaian serta peningkatan KPM matematik sebelum dan sesudah mendapatkan pembelajaran siswa yang pembelajarannya menggunakan pendekatan open ended dan pembelajaran biasa. 


\section{Analisis Data Pretes}

\section{a. Uji Normalitas}

Untuk menjawab hipotesis pada sebelum mendapatkan pembelajaran, dilakukan uji normalitas Shapiro Wilk dengan taraf siginfikansi $=0.05$.

Hasil perhitungan statistik dengan Software SPSS 25.0 berikut dalam Tabel 1.4 :

Tabel 4. Uji Normalitas data Pretes

\begin{tabular}{lcccc}
\hline \multirow{2}{*}{ Kelas } & \multicolumn{3}{c}{ Shapiro-Wilk } & \multirow{2}{*}{ Interpretasi } \\
\cline { 2 - 4 } & Statistic & $d f$ & Sig. & \\
\hline Pendekatan Open Ended & 0,879 & 21 & 0,014 & $\mathrm{H}_{0}$ ditolak \\
Pendekatan Biasa & 0,801 & 21 & 0,001 & \multirow{2}{*}{$\mathrm{H}_{0}$ ditolak } \\
\hline
\end{tabular}

Berdasarkan Tabel 1.4, terlihat bahwa taraf signifikasi yang didapatkan oleh kelas eksperimen sebesar 0,014, sedangkan taraf signifikasi kelas kontrol sebesar 0,001, karena nilai signifikasi dari kedua kelas $\leq 0,05$. Menunjukan bahwa hasil data prestes pada kedua kelas berasal dari data yang tidak berdistrubusi normal. Selanjutnya dilakukan uji hipotesis non-parametik yaitu uji Mann-Whitney.

\section{b. Uji Mann-Whitney data Pretes}

Selanjutnya dilakukan uji Mann-Whitney berikut dalam Tabel 1.4 :

Tabel 5. Uji Mann-Whitney data Pretes

\begin{tabular}{lr}
\hline & Hasil Belajar Siswa \\
\hline Mann-Whitney $U$ & 200,000 \\
Wilcoxon $W$ & 431,000 \\
$Z$ & $-0,535$ \\
Asymp. Sig. (2- & 0,593 \\
tailed) & \\
\hline
\end{tabular}

Berdasarkan Tabel 1.5, terlihat bahwa Asymp.Sig (2-Tailed) yang didapatkan sebesar 0.593, ini menunjukan Asymp.Sig dari hasil data pretes $\geq 0.05$. Yaitu dapat dijelaskan bahwa tidak terdapat perbedaan kemampuan awal kelas eksperimen dan kelas kontrol sebelum mendapatkan pembelajaran.

\section{Analisis Data Postes}

\section{a. Uji Normalitas Postes}

Untuk menjawab hipotesis pada sebelum mendapatkan pembelajaran, dilakukan uji normalitas Shapiro Wilk dengan taraf siginfikan $=0.05$. Hasil perhitungan statistik dengan Software SPSS 25.0 berikut dalam Tabel 1.6 :

Tabel 6. Uji Normalitas data Postes

\begin{tabular}{lcccc}
\hline \multirow{2}{*}{ Kelas } & \multicolumn{3}{c}{ Shapiro-Wilk } & \multirow{2}{*}{ Interpretasi } \\
\cline { 2 - 4 } & Statistic & $D f$ & Sig. & \\
\hline Pendekatan Open Ended & 0,908 & 21 & 0,051 & $\mathrm{H}_{0}$ diterima \\
Pendekatan biasa & 0,932 & 21 & 0,152 & $\mathrm{H}_{0}$ diterima \\
\hline
\end{tabular}

Berdasarkan Tabel 1.6, terlihat bahwa taraf signifikasi kedua kelas masing-masing untuk kelas eksperimen sebesar 0,051, sedangkan kelas kontrol sebesar 0,152, karena nilai signifikasi dari 
kedua kelas $\leq 0,05$. Ini menunjukan bahwa hasil postes dari kedua kelas berasal dari data yang berdistrubusi normal.

\section{b. Uji Homogenitas Postes}

Pada tahap selanjutnya akan dilakukan uji homogenitas pada hasil postes, berikut ditunjukan pada Tabel 1.7 :

Tabel 7. Uji Homogenitas Postes

\begin{tabular}{ccc}
\hline & Sig. & Interpretasi \\
\hline Based on Mean & 0,004 & Tidak sama \\
\hline
\end{tabular}

Berdasarkan Tabel 1.7, pada data postes kelas ekperimen dan kontrol nilai signifikansi $<0,05$ yang menyatakan bahwa varians data dari kedua kelas tidak sama.

\section{c. Uji Perbedaan Rata-rata Postes}

Selanjutnya dilakukan uji perbedaan rerata dengan independent sampel t' test pada hasil postes, berikut ditunjukan pada Tabel 1.8 :

Tabel 8. Uji independent sampel t' test

(Equal variances not assumed )

\begin{tabular}{cc}
\hline & Postest \\
\hline $\begin{array}{c}\text { Asymp. Sig. } \\
\text { tailed })\end{array}$ & 0,000 \\
\hline
\end{tabular}

Berdasarkan Tabel 1.8, nilai Sig. (2-tailed) yang didapat sebesar 0,000, untuk nilai 1-tailed (Uyanto, 2009) adalah $\frac{0,000}{2}=0,00<0,050$, maka $\mathrm{H}_{0}$ ditolak, ini menunjukan bahwa pencapaian KPM matematik dengan pendekatan open ended lebih baik daripada pendekatan biasa.

\section{Analisis N-Gain}

\section{a. Uji Normalitas N-Gain}

Pada tahap terakhir dilanjutkan uji $N$-gain berikut ditunjukan pada Tabel 1.9 :

Tabel 9. Hasil Analisis Uji Normalitas Data N-gain

\begin{tabular}{lrrrr}
\hline \multirow{2}{*}{ Kelas } & \multicolumn{3}{c}{ Shapiro-Wilk } & \multirow{2}{*}{ Interpretasi } \\
\cline { 2 - 4 } & Statistic & df & Sig. & \\
\hline Pendekatan Open Ended & 0,908 & 21 & 0,123 & $\mathrm{H}_{0}$ diterima \\
Pendekatan Biasa & 0,932 & 21 & 0,200 & $\mathrm{H}_{0}$ diterima \\
\hline
\end{tabular}

Berdasarkan Tabel 1.9 terlihat bahwa nilai signifikansi kelas eksperimen dan kelas kontrol memliki nilai siginifikan $\geq 0,05$ maka $\mathrm{H}_{0}$ diterima. Dengan kata lain bahwa data $N$-gain kedua kelas berasal dari data yang berdistribusi normal.

\section{b. Uji Homogenitas N-Gain}

Pada tahap selanjutnya akan dilakukan uji homogenitas berikut pada tabel 1.10 :

Tabel 10. Uji Homogenitas N-Gain

\begin{tabular}{lcc}
\hline & Sig. & Interpretasi \\
\hline Based on Mean & 0,05 & Tidak sama \\
\hline
\end{tabular}


Berdasarkan Tabel 1.10, terlihat bahwa nilai signifikansi rata-rata dari kedua kelas tersebut sebesar 0,05 , ini menunjukan bahwa data $N$-gain uji homogenitas nilai signifikansi sama dengan 0,05 sehingga dapat diketahui bahwa varians data hasil postes kedua kelas heterogen atau tidak sama.

\section{c. Uji Perbedaan Rata-rata N-Gain}

Selanjutnya dilakukan uji perbedaan rerata dengan independent sampel t' test pada data $\mathrm{N}$-Gain, berikut ditunjukan pada Tabel 1.11 :

Tabel 11. Uji independent sampel t' test Data Gain Ternormalisasi

(Equal variances not assumed )

\begin{tabular}{ccc}
\hline & $\boldsymbol{N}$-gain & Interpretasi \\
\hline Asymp. Sig. (2-tailed) & 0,000 & $\mathrm{H}_{0}$ ditolak \\
\hline
\end{tabular}

Berdasarkan Tabel 1.11 untuk nilai Sig. (2-tailed) yang didapat sebesar 0,000, untuk nilai 1tailed (Uyanto, 2009) adalah $\frac{0,000}{2}=0,00<0,050$, maka $\mathrm{H}_{0}$ ditolak, hal ini menunjukan bahwa peningkatan KPM matematik dengan pembelajaran ope berani mengajukan pendapat $n$ ended lebih baik daripada pembelajaran biasa.

\section{Pembahasan}

Berdasarkan hasil dari analisis penelitian yang telah dilakukan, pembelajaran yang dipilih dengan menggunakan pendekatan open ended, memberikan dampak perbaikan proses belajar yang dilakukan di kelas eksperimen. Peningkatan KPM pada kelas eksperimen sebesar 0,46 menunjukan bahwa peningkatan KPM pada kelas eksperimen memiliki intepretasi sedang. Selain itu, Pencapaian dan peningkatan KPM siswa yang mendapatkan pembelajaran open ended lebih baik dari pada pembelajaran biasa. Hasil penelitian ini tidak berbeda jauh dengan hasil penelitian yang dilakukan oleh Gordah (2012) dan Delyana (2015) yang menyebutkan bahwa pembelajaran yang diberikan menggunakan pendekatan open ended, menjadikan KPM matematik meningkat. Namun hal ini tidak berarti bahwa yang pembelajaran biasa adalah pembelajaran yang jelek, akan tetapi pembelajaraan biasa bersifat kurang terbuka, sehingga siswa kurang dalam melakukan eksplorasi dalam mengkontruksi suatu permasalahan yang dihadapi.

Kondisi seperti terlihat dari adanya kemampuan siswa yang menemukan konsep dan dapat menerapkannya dengan memberikan contoh-contoh dalam kehidupan di luar sekolah, siswa lebih percaya diri ketika mengajukan pendapat, gagasan dan pertanyaannya. Dari proses mengerjakan soal-soal KPM yang diberikan oleh guru terdapat variasi pengerjaannya, namun secara umum hasilnya sama. Siswa juga dilibatkan dalam mengoreksi pekerjaan sehingga dapat mengetahui jawaban yang benar atau yang salah. Hal ini tidak terlepas dari pendekatan open ended dalam proses belajarnya lebih menekankan keterlibatan siswa untuk berfikir terbuka dan guru hanya sebagai fasilitator saja.

Pembelajaran yang dilakukan dikelas pun peneliti selalu menyelipkan sebuah motivasi untuk siswa, selalu memotivasi siswa agar lebih baik lagi dalam belajar, lebih berani, dengan memberikan reward dengan kata-kata positif yang mendorong siswa untuk lebih aktif, selain itu guru membangkitkan rasa keingin tahuan siswa dengan memberikan beberapa pertanyaan pengantar sebelum memberikan materi. Menurut penelitian (Abbas, 2017) yang menyatakan bahwa reward digunakan untuk memperkuat respon positif atau respon negatif. Guru juga mengarahkan siswa berfikir kritis agar mampu menyelesaikan masalah-masalah yang 
dihadapinya. Pada awal pembelajaran yaitu pada pertemuan pertama, tidak banyak siswa yang berani mengajukan pertanyaan, mengembangkan gagasan atau memberikan komentar terhadap siswa lain. Sehingga guru masih harus memotivasi siswa atau menyuruh siswa tertentu untuk maju kedepan kelas untuk mempresentasikan hasilnya dan pada pertemuan kedua, ketika siswa dikelompokan untuk bekerjasama dan berdiskusi melaksanakan instruksi guru. Sejalan dengan (Sahrudin, 2014) yang menyatakan bahwa siswa bekerjasama satu dengan yang lainnya dalam satu kelompok belum terlihat kerjasamanya, ada beberapa kelompok yang didominasi oleh satu atau dua orang siswa dalam penyelesaiannya. Namun aktivitas pembelajaran meningkat pada pertemuan-pertemuan ganjil dan genap berikutnya kerjasama antar anggota kelompok sudah meningkat tampak dari keterlibatan siswa dalam menyelesaikan dan melaksanakan instruksi yang diberikan guru dan jumlah siswa yang menyampaikan gagasan juga meningkat terlihat dari banyaknya siswa yang mengerjakan soal di depan kelas.

\section{KESIMPULAN}

Berdasarkan hasil penelitian yang telah dilakukan mengenai KPM matematik siswa MA maka dapat disimpulkan bahwa :

1. Peningkatan KPM pada kelas yang pembelajarannya menggunkan pendekatan open ended memiliki interpretasi sedang.

2. Pencapaian dan peningkatan KPM matematik siswa MA yang pembelajarannya menggunakan pendekatan open ended lebih baik daripada pendekatan biasa.

3. Pendekatan open ended mampu menekankan dan menjadikan siswa dapat belajar lebih aktif dan berpikir secara kritis dan terbuka.

\section{DAFTAR PUSTAKA}

Akbar, P., Hamid, A., Bernard, M., \& Sugandi, A. I. (2018). Analisis kemampuan pemecahan masalah dan disposisi matematik siswa kelas XI SMA Putra Juang dalam materi peluang. Jurnal Cendekia: Jurnal Pendidikan Matematika, 2(1), 144-153.

Aripin, U. (2015). Meningkatkan Kemampuan Pemahaman Matematik Siswa SMP Melalui Pendekatan Pembelajaran Berbasis Masalah. P2M STKIP Siliwangi, 2(1), 120-127

Delyana, H. (2015). Peningkatan Kemampuan Pemecahan Masalah Matematika Siswa Kelas VII Melalui Penerapan Pendekatan Open Ended. Lemma, 2(1).

Faridah, N., \& Aeni, A. N. Pendekatan open ended untuk meningkatkan kemampuan berpikir kreatif matematis dan kepercayaan diri siswa. Jurnal pena ilmiah, 1(1), 1061-1070.

Gordah, (2012). Meningkatkan Kemampuan Koneksi dan Pemecahan Masalah Matematik melalui Pendekatan Open Ended. Tesis. PPS UPI. Tidak Diterbitkan.

Hendriana \& Sumarmo. (2014) Penilaian dan Pengukuran dalam Pembelajaran Matematika. Cimahi: Nusantara Membaca. 
Hutajulu, M. (2017). Pembelajaran Matematika Melalui Pendekatan Keterampilan Metakognitif Dengan Model Advance Organizer untuk Meningkatkan Kemampuan Berpikir Kritis Matematik Siswa SMA. Jurnal Edukasi dan Sains Matematika (JESMAT), 3(1), 21-32.

Hutajulu, M., \& Minarti, E. D. (2017). Meningkatkan Kemampuan Advanced Mathematical Thinking Dan Habits Of Mind Mahasiswa Melalui Pendekatan Keterampilan Metakognitif. Jurnal Edukasi dan Sains Matematika (JES-MAT), 3(2), 177-194.

Ruseffendi, E. T. (2010). Dasar-dasar Penelitian Pendidikan \& bidang Non Eksanta Lainnya. Bandung: Tarsito

Sugandi, A. I. (2010). Pengaruh Pembelajaran Berbasis Masalah dengan Setting Kooperatif Tipe Jigsaw Terhadap Pencapaian Kemampuan Berpikir Matematik Tingkat Tinggi dan Kemandirian Belajar Siswa SMA (Doctoral dissertation, Universitas Pendidikan Indonesia).

Uyanto, Stanislaus S. (2009). Pedoman Analisis Data dengan SPSS. Yogyakarta: Graha Ilmu

Yulianingsih, R. (2013). Penerapan Model Pembelajaran Based Learning dengan Teknik Scaffolding untuk Meningkatkan Kemampuan Pemecahan Masalah Matematik Siswa SMA. Bandung: Jurnal.Upi. [Online]. Tersedia http://respository.upi.edu/386/4/S_MTK_0900629 CHAPTER1.pdf

Sahrudin A., (2014) . Implementasi Strategi Pembelajaran Discovery untuk Meningkatkan Kemampuan Pemecahan Masalah Matematis dan Motivasi Belajar Siswa SMA. Jurnal Pendidikan UNSIKA 2(1), 2338-2996

Setiawan, R. H., \& Harta, I. (2014). Pengaruh pendekatan open-ended dan pendekatan kontekstual terhadap kemampuan pemecahan masalah dan sikap siswa terhadap matematika. Jurnal Riset Pendidikan Matematika, 1(2), 241-257. 